\title{
Model Pemberdayaan Ekonomi Terhadap Kemandirian Masjid Haji Maraset \\ Jl. Sei Deli Kecamatan Medan Barat
}

\author{
Muhammad Arif \\ Fakultas Ekonomi dan Bisnis Islam Universitas Islam Negeri Sumatera Utara \\ muhammad4rif@yahoo.co.id
}

\begin{abstract}
This research examines economic empowerment in mosque independence. This study uses a qualitative research method by means of observation, namely researchers conduct observations and interviews directly with the parties concerned, especially advisors, chairpersons, and members of ta'mir Maraset Hajj mosque. The results are analyzed by stages of data reduction, data presentation and verification or make conclusions. This research was conducted to determine the extent of economic development concept of Hajj Maraset mosque, explaining the implementation of economic empowerment in managing the economic potential on Hajj Maraset mosque, and identifying mosques contribution to the welfare of the community in the Maraset Hajj mosque. An economic role that has not been maximized, researchers offer: mosque development-based culinary businesses, mosque development-based mini markets, banks, and if the mosque has more land, the mosque develops cattle, goats and chickens with cutting services in accordance with Islamic sharia. There are three reasons for the Haji Maraset mosque to be categorized as an independent mosque: it can fund activities planned by the mosque by optimizing the potential sources of funds owned by the mosque, has the ability to produce income professionally through optimizing asset empowerment, and managing professionalism in all activities and prosperity of the mosque.
\end{abstract}

Keywords: Economic Empowerment, Mosque Independence, Mosque Contribution, Community Welfare, Mosque-Based Culinary Business

\begin{abstract}
Abstrak
Penelitian ini meneliti tentang pemberdayaan ekonomi pada kemandirian masjid. Penelitian ini menggunakan metode penelitian secara kualitatif dengan cara observasi yaitu peneliti melakukan pengamatan dan wawancara secara langsung dengan pihak-pihak yang bersangkutan, terutama penasehat, ketua, dan para anggota ta'mir masjid Haji Maraset. Penelitian ini dilakukan untuk mengetahui sejauh mana konsep pengembangan ekonomi masjid Haji Maraset, menjelaskan implementasi pemberdayaan ekonomi dalam mengelola potensi ekonomi masjid Haji Maraset, serta mengidentifikasikan kontribusi masjid terhadap kesejahteraan masyarakat di lingkungan masjid Haji Maraset. Adanya peran ekonomi yang belum maksimal, peneliti menawarkan: pengembangan bisnis kuliner berbasis masjid, pengembangan mini market berbasis masjid, bank masjid, dan jika masjid memiliki tanah yang lebih luas, masjid mengembangkan peternakan lembu, kambing dan ayam dengan jasa pemotongan yang sesuai syariah Islam. Ada tiga alasan masjid Haji Maraset diketegorikan masjid yang
\end{abstract}


mandiri: dapat mendanai kegiatan-kegiatan yang telah direncanakan masjid dengan optimalisasi potensi sumber dana yang dimiliki oleh masjid, memiliki kemampuan untuk menghasilkan pendapatan secara profesional melalui optimalisasi pemberdayaan asset masjid, dan profesionalisme manajemen dalam seluruh kegiatan dan pemakmuran masjid.

Kata Kunci: Pemberdayaan Ekonomi, Kemandirian Masjid, Kontribusi Masjid, Kesejahteraan Masyarakat, Bisnis Kuliner Berbasis Masjid

\section{Pendahuluan}

Perkembangan umat Islam pada periode awal tidak lepas dari masjid. Masjid adalah suatu tempat (bangunan) yang fungsi utamanya sebagai tempat shalat bersujud menyembah Allah SWT. Firman Allah SWT dalam QS al-Jinn' (72): 18

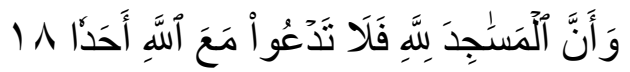

Artinya: "Dan sesungguhnya masjid-masjid itu adalah kepunyaaan Allah. Maka janganlah kamu menyembah seseorang pun di dalamnya di samping (menyembah) Allah",

Di samping sebagai tempat beribadah umat Islam dalam arti khusus (mahdhah), masjid juga merupakan tempat beribadah secara luas (ghairu mahdhah) selama dilakukan dalam batas-batas syari'ah. Masjid yang besar, indah dan bersih adalah dambaan kita, namun semua itu belum cukup apabila tidak ditunjang dengan kegiatan-kegiatan memakmurkan masjid. ${ }^{2}$

Masjid memiliki kedudukan dan peran yang sangat penting bagi Umat Islam dalam membentuk karakter masyarakat yang islami. Karena penting itulah, masjid harus difungsikan dengan sebaik-baiknya. Menurut Ahmad Yani, masjid yang fungsinya dapat dioptimalkan secara baik adalah masjid yang didirikan atas dasar taqwa. ${ }^{3}$ Keberlangsungan aktifitas masjid seharusnya muncul dari inisiatif pengurusnya, apabila pengurusnya berani, maka "hiduplah" masjid itu. Sebaliknya apabila pengurus masjid "loyo", tidak akan ada transformasi semangat yang lahir dari masjid yang memberikan ruhnya pada aktifitas jama'ah. ${ }^{4}$

Sejauh ini, ada juga beberapa masjid yang menjalankan peran ibadah, pendidikan, dan ekonomi masjid, walaupun peran dan fungsi yang digarap belum maksimal dijalankan dengan tujuan agar bisa menjadi masjid yang mandiri, artinya masjid tidak hanya bergantung pada dana jama'ah. ${ }^{5}$ Pada masa Rasulullah SAW memberi contoh kepada kita bahwa bahan bangunan masjid diperoleh 
disekitar beliau, Karena penekanannya bukan pada bentuk bangunan fisiknya melainkan agar dapat segera berfungsi sebagai pusat pembinaan umat disekitarnya. ${ }^{6}$ Pada masa sekarang, pembangunan masjid sangat pesat seiring dengan bertambahnya jumlah penduduk dan kesadaran masyarakat akan pentingnya ibadah shalat, sehingga masjid selalu ada di setiap tempat baik itu di pedesaan maupun perkotaan yang meliputi kantor swasta, kantor pemerintahan, lembaga pendidikan, tempat rekreasi, mall atau pasar dan tempat-tempat publik lainnya di sediakan tempat untuk shalat. ${ }^{7}$

Salah satu pilar kemajuan peradaban Islam adalah amwal (wealth) atau ekonomi. Dalam hal ini, Ibnu Khaldun mengatakan "Ekonomi adalah tiang dan pilar paling penting untuk membangun peradaban Islam (Imarah). Tanpa kemapanan ekonomi, maka kejayaan Islam sulit dicapai bahkan tak mungkin diwujudkan. Ekonomi penting untuk membangun negara dan menciptakan kesejahteraan umat. Sehingga tradisi keilmuwan ekonomi yang eksis di masa silam, harus dihidupkan kembali di masjid-masjid, agar fungsi masjid sebagaimana zaman Rasulullah dapat diwujudkan kembali khususnya masalah ekonomi. $^{8}$

Salah satu masjid yang dapat menjadi contoh keberhasilan kemandiriannya yaitu Masjid Haji Maraset, yang sampai sekarang salah satunya dengan pengelolaan yang dilakukan oleh para badan kenaziran masjid dengan model manajemen ekonomi yang terarah, yaitu membuat usaha seperti sewa ruko, sewa rumah, sewa kebon dan sekolah.

Tabel 1 Usaha Masjid Haji Maraset

\begin{tabular}{|l|lr|}
\hline Jenis Usaha & \multicolumn{2}{|l|}{ Pendapatan Pertahun } \\
\hline Sewa Ruko & $\mathrm{Rp}$ & 1.050 .000 .000 \\
\hline Sewa Rumah & $\mathrm{Rp}$ & 165.000 .000 \\
\hline Sewa Kebon & $\mathrm{Rp}$ & 200.000 .000 \\
\hline SD Arsyadiah & $\mathrm{Rp}$ & 144.000 .000 \\
\hline Jumlah & $\mathrm{Rp}$ & 1.559 .000 .000 \\
\hline
\end{tabular}

Dari tabel diatas maka dapat kita melihat bahwa Masjid Haji Maraset memilki usaha-usaha yang menjanjikan sehingga kemandirian masjid tersebut dari sudut pandang ekonomi bisa tercapai. Dilihat dari jenis usahanya yaitu sewa ruko, sewa rumah, sewa kebun dan sekolah dimana pendapatannya pertahun sudah lebih 
dari cukup untuk memenuhi operasional masjid. Upaya-upaya inilah yang menjadikan sebuah kemandirian secara ekonomi, dimana masjid tidak hanya mampu menghidupkan masjid itu sendiri, tetapi juga mampu memberikan kesejahteraan dan kemakmuran untuk umat.

Dan setelah dihitung-hitung oleh pengelola keuangan masjid dari usahausaha ini mengalami keuntungan tiap tahunnya, dari sewa ruko yang pendapatannya mencapai $\mathrm{Rp} 1.050 .000 .000,-$, pertahun dan sewa rumah mencapai Rp 165.000.000,-, pertahun dan ditambah hasil sewa kebon mencapai Rp 200.000.000,-, pertahun, Sedangkan pendapatan dari SD Arsyadiah yang mencapai Rp 144.000.000,-. Dari jumlah semua usaha ini sudah bisa melestarikan dan memakmurkan Masjid Haji Maraset. Pendapatan dari SD Arsyadiah dijadikan untuk pengelolaan sekolah tersebut, kecuali sewaktu-waktu ada alasan lain untuk keperluan masjid. Hal ini dibuat karena keuangan masjid pertahunnya sudah mencukupi dan keuangan masjid memiliki daya tahan dan memiliki keberkahan yang sangat besar. ${ }^{9}$

\section{Metode Penelitian}

Penelitian ini dilaksanakan dengan pendekatan kualitatif, karena fokus penelitiannya adalah Model Pemberdayaan Ekonomi dalam Kemandirian Masjid. Penelitian kualitatif merupakan suatu strategi inqury yang menekankan pencarian makna, pengertian, konsep, karakteristik, gejala, simbol, maupun deskripsi tentang suatu fenomena; fokus dan multimetode, bersifat alami dan holistik; mengutamakan kualitas, menggunakan beberapa cara, serta disajikan naratif. Dari sisi lain dan secara sederhana dapat dikatakan bahwa tujuan penelitian kualitatif adalah untuk menemukan jawaban terhadap suatu fenomena atau pertanyaan melalui aplikasi prosedur ilmiah secara sistematis dengan menggunakan pendekatan kualitatif. ${ }^{10}$

Rulam Ahmadi dalam Metodologi Penelitian Kualitatif mengutip dari Bogdan dan Taylor, mendefinisikan metode kualitatif sebagai prosedur penelitian yang menghasilkan data deskriptif berupa kata-kata tertulis atau lisan dari orangorang atau pelaku yang dapat diamati dari orang-orang (subjek) itu sendiri. ${ }^{11}$

Pendekatan ini merupakan suatu proses pengumpulan data secara sistematis dan intensif untuk memperoleh pengetahuan tentang pemberdayaan 
ekonomi dan pengaruhnya terhadap kemandirian Masjid, yang mana penelitian ini dilakukan di Masjid Haji Maraset Medan Barat.

\section{Pembahasan}

\section{Konsep Pengembangan Potensi Ekonomi Masjid Haji Maraset}

Masjid Haji Maraset yang diresmikan penggunaannya pada tahun 1932, dibangun atas dasar keinginan luhur untuk menjadi pusat ibadah dan penyebaran ajaran Islam serta menjadi wahana pembinaan umat yang beriman dan bertaqwa kepada Allah SWT. Masjid Haji Maraset dengan posisinya yang strategis di kawasan pinggir sungai Deli diharapkan mampu memberi manfaat yang sangat besar bagi pengembangan ajaran Islam dan penataan yang Islami.

Pada satu sisi, masjid adalah suatu bangunan yang kokoh kuat, tidak bergerak dan bersifat statis, akan tetapi pada sisi yang lain, masjid berfungsi sebagai wahana ibadah dan dakwah (pembinaan sumber daya manusia). Dengan pandangan seperti ini masjid bersifat dinamis, berkembang meluas dan dapat menarik minat masyarakat sekitarnya untuk melakukan ibadah, mendalami dan menyebarkan ajaran Islam serta mengembangkan ukhuwah islamiyah.

Untuk merealisasikan hal tersebut di atas, Masjid Haji Maraset menyadari betul bahwa kegiatan-kegiatan yang dilakukan oleh masjid tidak bisa terlepas dari persoalan pendanaan, oleh karena itu, untuk mengatasi persoalan pendanaan Masjid Haji Maraset baik kegiatan dakwah maupun kegiatan operasional, DKM Masjid Haji Maraset tidak ingin hanya mengandalkan bantuan saja, akan tetapi DKM masjid juga melakukan beberapa kegiatan usaha untuk bisa mengurangi atau bahkan mungkin bisa menutupi dana-dana yang dibutuhkan untuk melakukan aktifitas pemakmuran masjid. Hal ini dilakukan oleh DKM masjid karena melihat potensi yang cukup besar untuk bisa mengembangkan sebuah kegiatan usaha yang berbasis masjid.

Masjid Haji Maraset sebelum memutuskan akan melakukan kegiatan usaha, pihak DKM masjid melakukan sebuah riset kecil yang bertujuan untuk mengetahui apa kebutuhan masyarakat di lingkungan sekitar masjid agar kegiatan usaha yang digerakkan oleh masjid nantinya dapat berjalan dengan efektif seperti yang diharapkan oleh pengurus masjid dan masyarakat pun akan merasa terbantu dengan keberadaannya. 
Beberapa upaya yang dilakukan oleh DKM Masjid Haji Maraset saat ini yaitu dengan mengembangkan sebuah kegiatan usaha yang meliputi sekolah SD, sewa kebun, sewa rumah, dan sewa ruko. Hasil dari usaha inipun kini sudah banyak dirasakan manfaatnya oleh masyarakat yang merasa terbantu dengan kegiatan usaha ini, dan khususnya bermanfaat terhadap kegiatan masjid.

Sebagaimana yang telah diuraikan di atas sebelumnya tentang bidang usaha yang dimiliki Masjid Haji Maraset, akan diuraikan dengan pertimbangan analisa potensi yang dimiliki masing-masing bidang usaha yang dapat menunjang optimalisasi sumber dana masjid.

\section{a. Sekolah Dasar}

SD merupakan upaya mencerdaskan dan mencetak kehidupan bangsa dan bertaqwa, cinta dan bangga terhadap bangsa dan negara, terampil, kreatif, berbudi pekerti yang santun serta mampu menyelesaikan permasalahan dilingkungannya. ${ }^{12}$

Manajerial pengembangan sekolah dasar di masjid Haji Maraset ada dalam koordinasi kepala sekolah. Struktur permodalan sekolah dari kas masjid sebagai penyetor permodalan dana awal, selanjutnya dari pihak ketiga yang menjadi murid sekolah dengan pembayaran uang sekolah.

Adapun program pelaksanaan kegiatan melanjutkan usaha yang ada berupa sekolah dengan penghitungan kembali modal awal sejak pengelolaan sekolah diserahkan ke bidang usaha. Pengelolaan sekolah dibawah tanggung jawab bidang usaha dengan tenaga pengelola yang akan diusahakan oleh penanggung jawab Sekolah.

Kegiatan awal sekolah berupa sarana pembelajaran dengan mengedepankan mencerdaskan anak-anak, dengan ini diharapkan agar anak-anak mampu memahami pelajaran dan mengikuti zaman sehingga mampu menyelesaikan permasalahannya. Selain itu uang sekolah anak perbulan juga diutamakan agar sekolah terus berkembang produktif bukan hanya memenuhi kebutuhan konsumtif semata. Namun seiring perjalanannya sering kali memenuhi kendala dan hambatan sehingga pada saat ini sekolah hanya bergerak di bidang pembelajaran teori saja.

Hal ini akan memberikan sebuah tantangan kepada kepala sekolah dan tenaga pengajar lainnya untuk meningkatkan tahap pendidikan bukan sekedar teori, akan tetapi memulai praktik-praktik sesuai pelajaran yang diberikan. 
Sementara dilihat dari segi lokasi, sekolah SD Arsyadiyah ini sekolah yang sangat bagus dan strategis karena lokasinya masih asri, sejuk, nyaman dan tidak tercemari kebisingan.

Dalam laporan keuangan sekolah arsyadiyah saldo sekolah tahun 2017 sejumlah Rp. 15.850.000,-- ${ }^{13}$ Dan ditahun 2018 ini laporan pemasukan sekolah Arsyadiyah dari bulan Januari sampai dengan September berjumlah Rp. 4.143.000,- ${ }^{14}$

\section{b. Usaha Penyewaan}

Untuk menopang pemasukan masjid tidak cukup hanya mengandalkan dari hasil keuntungan sekolah saja. Oleh karena itu Masjid Haji Maraset mengembangkan usaha-usaha lainnya untuk membantu pemasukan masjid dalam rangka menjadikan masjid yang mandiri.

Adapun usaha yang dilakukan oleh masjid ialah dengan menyewakan rumah, ruko dan kebun karet yang dibangun masjid. Saat ini rumah dan ruko yang dibangun masjid berjumlah 32 pintu. Penyewaan ini disewakan kepada masyarakat yang membutuhkan untuk tempat tinggal atau buka usaha, dan untuk penyewa dikenakan pembayaran pertahun sesuai akad kesepakatan.

Hasil laporan pemasukan total dari usaha-usaha penyewaan masjid Haji Maraset di tahun 2017 sejumlah Rp 1.413.500.000,-. Dan untuk tahun 2018 ini hingga pelaporan per september 2018 pemasukan dari hasil penyewaan berjumlah Rp 1.366.250.000,--. ${ }^{15}$

Semua usaha yang dikelola oleh bidang usaha selalu berpegang teguh pada azas usaha berdasarkan tuntunan syariat Islam. Setiap kebijakan yang menyangkut kegiatan usaha yang dilakukan oleh penanggung jawab bidang usaha harus berdasarkan koordinasi dan kesepakatan semua pengurus dan anggota bidang usaha dengan persetujuan pengurus masjid dan tidak menyimpang dari visi, misi serta program masjid secara keseluruhan.

Kekurangan sumber daya manusia dalam pelaksanaan kegiatan usaha tersebut. karena selama ini pengurus masjid Haji Maraset merupakan orang-orang pekerja yang kesehariannya sibuk dengan rutinitas mereka masing-masing dan hanya bisa fokus dalam kegiatan masjid pada saat libur kerja atau libur-libur nasional. Sedangkan yang selalu ada di masjid hanya beberapa orang saja, sehingga ada beberapa program yang dirancang tidak dapat berjalan dengan sebagaimana mestinya. 
Kegiatan usaha masjid ini didirikan atas dasar keinginan Almarhum Bapak Hasan Parinduri selaku ketua DKM masjid pada masa itu dan seluruh pengurus masjid agar Masjid Haji Maraset mampu berkembang mandiri secara ekonomi kedepannya dengan memanfaatkan segala potensi yang tersedia secara maksimal. $^{16}$

Pengembangan bidang usaha yang dilakukan semata-mata bertujuan untuk kemakmuran masjid itu sendiri, sehingga masjid mampu "membiayai hidupnya sendiri”, artinya bahwa masjid tidak selalu sepenuhnya bergantung terhadap bantuan-bantuan dalam setiap kebutuhan yang diperlukan, karena Masjid Haji Maraset kini sudah memiliki alokasi dana yang diperoleh dari hasil kegiatan usaha untuk membiayai kegiatan-kegiatan masjid. Pendapatan Masjid Haji Maraset dari kegiatan usaha sudah mampu menutupi seluruh aktifitas masjid, ditambah pemasukan yang diperoleh dari para donatur membantu mengurangi beban pengeluaran masjid yang tidak sedikit.

Pendapatan dari hasil kegiatan usaha Masjid Haji Maraset selain untuk kegiatan operasional masjid juga digunakan untuk kegiatan-kegiatan pemakmuran masjid dengan mengadakan berbagai kajian-kajian tentang wawasan keislaman, kegiatan sosial seperti santunan anak yatim, beasiswa pendidikan bagi yang tidak mampu, dan bakti sosial di perkampungan sekitar.

Model Pemberdayaan ekonomi yang dilakukan oleh Masjid Haji Maraset pun makin dirasakan manfaatnya baik oleh pengurus masjid maupun masyarakat dan jama'ah, seiring dengan peluang-peluang usaha yang diberikan oleh masjid baik berupa penyewaan tempat usaha, yang pengelolaan keuangannya berdasarkan dengan prinsip syari'ah.

Masjid Haji Maraset senantiasa berupaya melakukan perbaikan-perbaikan yang berkelanjutan terhadap kinerja kepengurusan khususnya bidang usaha agar senantiasa mampu menghasilkan kreasi, inovasi-inovasi terbaru dan mengoptimalkan potensi-potensi yang melekat pada masjid agar tidak tergantung pada pihak manapun, termasuk infaq jama'ah yang selama ini menjadi tumpuan mayoritas masjid di Indonesia sehingga dapat meningkatkan pendapatan kas masjid. Dengan begitu akan semakin banyak kegiatan yang dapat dilaksanakan masjid dan harapannya akan semakin banyak pula jama'ah yang ikut berpartisipasi dalam aktifitas pemakmuran masjid. 
Manajemen keuangan sebagai pola penentuan kebijakan dalam mengalokasikan dana yang masuk (income) dan membelanjakannya dalam bentuk pembiayaan dan biaya-biaya operasional untuk kelangsungan pemeliharaan visi dan misi suatu organisasi, terkait dengan Masjid sebagai organisasi nirlaba (non profit organisation), tentu dengan tidak berazas profit oriented (pure bisnis) tapi dituntut untuk eksis sebagai organisasi yang dapat memberikan kontribusi yang maksimal dalam menjalankan fungsinya sebagai Institusi pembinaan umat. Walau demikian Masjid sebagai sebuah organisasi yang memiliki kemampuan untuk menghasilkan pemasukan yang maksimal untuk membiayai seluruh aktifitasnya, sehingga tidak menghambat visi Masjid secara de facto. Membutuhkan kebijakan baku yang dapat mengatur manajemen keuangannya.

Dalam hal ini Masjid Haji Maraset memiliki panduan teknis berlandaskan atas Prinsip "BERDIKARI" dengan maksud bahwa pengurus tidak menggantungkan diri semata-mata dari sokongan pemerintah, golongan tertentu maupun perorangan, tetapi menjadi kewajiban dan tanggung jawab Umat dan Masyarakat Islam pada umumnya, dan khususnya keturunan Haji Maraset.

Hasil pengumpulan dana dan zakat harus dicatat dengan mengadakan administrasi dan pembukuan yang rapi serta dapat dipertanggungjawabkan, tugas dari perbendaharaan untuk membuat anggaran belanja secara periodik (triwulan/tahunan) dan menjalankan kebijaksanaan keuangan yang telah digariskan oleh badan pengurus.

Semua pemasukan dan pengeluaran uang melalui bank, sedangkan untuk keperluan rutin dan harian disediakan kas kecil yang pemakaiannya dipertanggungjawabkan di bawah bimbingan dan pengawasan sekretaris.

Pembinaan keuangan (manajemen keuangan) dalam hal penerimaan keuangan yaitu dari kegiatan-kegiatan usaha masjid, dari sisa dana acara-acara hari besar Islam, dan dari infaq dan wakaf dari masyarakat atau pihak lain secara ikhlas tanpa ada unsur paksaan. Pengeluaran keuangan Masjid Haji Maraset dibagi kedalam tiga sub pokok meliputi:

a. Pengeluaran berkala (rutin) dimaksudkan untuk: beban gaji pegawai tetap, fee penceramah tetap, beban listrik, air dan pengeluaran sehari-hari

b. Pengeluaran sewaktu-waktu (insidentil) meliputi: ongkos-ongkos pemeliharaan masjid yang besar jumlahnya dan hanya sewaktu-waktu 
dibutuhkan dan pembiayaan-pembiayaan yang tidak termasuk pengeluaran berkala yang tidak terduga.

c. Pengeluaran khusus, untuk pembiayaan tambahan dan penyempurnaan bangunan yang tidak termasuk pengeluaran sewaktu-waktu.

d. Dengan demikian manajemen pengendalian keuangan masjid adalah kemampuan masjid untuk mengatur keuangan secara sistematis dan terarah dalam mewujudkan tujuan secara keseluruhan.

Tabel 2 Laporan Penerimaan Dan Pengeluaran Masjid Haji Maraset

Tahun 2017

\begin{tabular}{|l|r|l|}
\hline \multicolumn{1}{|c|}{$\begin{array}{c}\text { Jenis Penerimaan dan } \\
\text { Pengeluaran }\end{array}$} & Debet & Kredit \\
\hline Penerimaan & 144.000 .000 & \\
\hline Sekolah SD Arsyadiyah & 200.000 .000 & \\
\hline Kebon karet & 165.000 .000 & \\
\hline Sewa rumah & 1.050 .000 .000 & \\
\hline Sewa ruko & 24.000 .000 & \\
\hline Infaq & 6.000 .000 & \\
\hline Lain-lain & & \\
\hline Jumlah penerimaan & & 1.589 .000 .000 \\
\hline Biaya Operasional & 24.000 .000 & \\
\hline Insentif honor pengurus masjid & 24.000 .000 & \\
\hline Insentif hari jum'at & 50.000 .000 & \\
\hline Listrik, air dan PAM & 21.000 .000 & \\
\hline dakwah dan pengajian & 20.000 .000 & \\
\hline Kegiatan ramadhan & & \\
\hline Biaya kegiatan lain-lain & & \\
\hline Jumlah pengeluaran & & \\
\hline
\end{tabular}

\section{Kontribusi Masjid Terhadap Kesejahteraan Masyarakat}

Salah satu unsur penting dalam struktur masyarakat Islam adalah masjid. Masjid digunakan umat Islam dalam berbagai keperluan termasuk Masjid Haji Maraset. Kontribusi Masjid Haji Maraset terhadap masyarakat terdiri dari Ibadah, Pendidikan, Dakwah, Ekonomi, Sosial.

1. Ibadah 
Masjid dibangun untuk beribadah mendekatkan diri kepada Allah SWT. Peran ibadah masih berjalan di masjid, khususnya Masjid Haji Maraset. Salah satu bentuk ibadah di masjid zaman sekarang adalah menjadikan masjid sebagai tempat shalat wajib dan sunnah, sebagaimana tujuan manusia diciptakan ke muka bumi ini hanya untuk menyembah Allah SWT. Ibadah shalat yang dilaksanakan pada masjid meliputi shalat fardhu dan sunnah. Hal ini diungkapkan oleh Effendi (Anwar Effendi Nasution), ${ }^{17}$ bahwa:

"Ibadah shalat dimasjid kita dilakukan sesuai waktunya, shalat fardhu seperti subuh, zuhur, asyar, magrib dan isya dilakukan saat waktunya tiba. Selain itu, shalat jum'at juga dilaksanakan di masjid kita ini. Kalau untuk shalat sunnah, seperti shalat dhuha dan tahajjud, kita hanya menyediakan tempat jama'ah untuk melaksanakannya, tetapi kalau shalat sunnah lain seperti shalat hari raya, shalat gerhana bulan dan matahari, shalat tarawih dan witir, shalat tasbih, shalat istisqa', kita melakukannya berjama'ah dimasjid ini."

Effendi juga menegaskan bahwa jama'ah yang hadir pada pelaksanaan shalat fardhu dan sunnah sangat ramai. Hal ini juga di tuturkan oleh Ahmad Hasan, ${ }^{18}$ bahwa:

"Masjid Haji Maraset ini fisiknya agak lain yaitu unik tidak seperti masjid lainnya, tetapi jama'ah yang melaksanakan shalat fardhu dan sunnah lumayan ramai, sampai sampai harus menambah bangunan disamping kiri kanan masjid. Agar jama'ah tetap bisa ikut shalat berjama'ah di masjid."

Pada hakikatnya, dengan melaksanakan kewajiban shalat akan mampu menghindarkan diri dari perbuatan keji dan mungkar sebagaimana disebutkan dalam QS al-Ankabut (29): 45

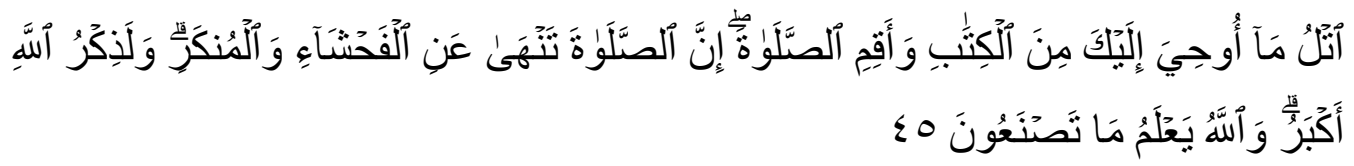

Artinya: "Bacalah apa yang telah diwahyukan kepadamu, yaitu Al Kitab (Al Qur'an) dan dirikanlah shalat. Sesungguhnya shalat itu mencegah dari (perbuatan-perbuatan) keji dan mungkar. Dan sesungguhnya mengingat Allah (shalat) adalah lebih besar (keutamaannya dari ibadat-ibadat yang lain). Dan Allah mengetahui apa yang kamu kerjakan." 19 
Shalat adalah rahmat Allah yang besar, mencari pertolongan dengan shalat ketika menghadapi kesulitan berarti menuju rahmat Allah, dan jika rahmat Allah datang, tidak akan ada lagi kesulitan. Sebagaimana hadist nabi SAW:

2. Pendidikan

Masjid adalah pusat pengajaran dan pendidikan, hal yang sama dilaksanakan oleh Masjid Haji Maraset. Pada Masjid Haji Maraset, Syarifuddin Lubis menuturkan bahwa:

"masjid kita ini memilki sekolah tingkat dasar (sekolah dasar) Islam. Sekolah dijadwalkan dari pagi jam 07:30 sampai dengan jam 14:00 setiap hari senin hingga sabtu WIB. Selain itu, untuk pendidikan lainnya, kami juga mengadakan kajian-kajian ilmu tafsir Al Qur'an, ceramah-ceramah agama untuk seluruh masyarakat serta memberikan pengajaran Al Qur'an untuk anak-anak.”

Peran pendidikan yang dijelaskan oleh pak Syarifuddin diatas sudah hampir maksimal dalam peranannya jika dibandingkan dengan peran pendidikan yang dilakukan pada masjid lain pada umumnya.

Masjid Haji Maraset mengadakan ceramah-ceramah agama serta memberikan pengajaran Al Qur'an bagi anak-anak. Tetapi, pendidikan dan pengajaran hanya diajarkan di bidang ilmu saja. Masyarakat tidak di bina dalam pendidikan iman dan akhlak. Alhasil, masyarakat sekarang memiliki kecerdasan ilmu pengetahuan namun miskin iman dan akhlak. Miskin iman dan akhlak ini dibuktikan dengan banyaknya kasus-kasus pelecehan seksual yang terjadi di zaman sekarang. ${ }^{20}$

3. Dakwah

Dakwah hampir sama dengan pengajaran. Namun, dakwah lebih kepada mengajak, menyeru, memanggil, beda dengan pengajaran yang hanya memberikan. Maka dari itu, harusnya dakwah melakukan pergerakan dalam menyerukan ilmu keimanan bukan hanya menunggu untuk diberikan ilmu keimanan. Namun, dakwah yang dilakukan pada zaman sekarang khususnya Masjid Haji Maraset hanya sebatas metodenya yaitu seperti ceramah dan pengajian. Harusnya, dakwah dilakukan dari teknisnya dahulu yaitu turun ke masyarakat untuk mengajak dan menyerukan ke masyarakat kemudian di bawa ke masjid dengan mengisi pengajian, ceramah, diskusi, dan atau seminar-seminar. Hal ini ditegaskan oleh penuturan Pardamean Lubis, ${ }^{21}$ bahwa: 
"Masjid kita untuk melakukan dakwah yang bergerak ke masyarakat masih belum bisa dilaksanakan karena untuk tim ahli dakwah yang akan dikirim kepada masyarakat tidak tersedia."

Seharusnya para da'i mengajak keluarga dan masyarakat untuk berdiskusi atau mengikuti pengajian agama. Sebagaimana dakwah yang dilakukan oleh Rasulullah yaitu mengirim beberapa sahabatnya ke berbagai negara untuk menyebarkan Islam kepenjuru dunia, seperti Mush'ab bin Umair yang dikirim ke Madinah oleh Rasulullah, beliau juga mengutus Ali bin Abi Thalib kepada sekelompok masyarakat Yaman yang masih merasa enggan sekali tunduk dibawah panji Islam, Ali ditugaskan untuk mengajak mereka ke dalam Islam. ${ }^{22}$

\section{Ekonomi}

Ekonomi merupakan bagian terpenting dalam memakmurkan masjid. Tanpa adanya ekonomi, setiap aktivitasnya yang akan dilaksanakan akan terhambat. Masjid Haji Maraset telah berusaha melaksanakan masjid mandiri dengan mengadakan penyewaan rumah dan ruko. Hal ini dituturkan oleh Syarifuddin Lubis:

"penyewaan rumah dan ruko yang dilakukan masjid bertujuan untuk mendapatkan kas masjid, sehingga kebutuhan masjid terpenuhi, tidak perlu membuat kotak infak dipinggir jalan yang menurunkan citra baik muslim dengan meminta-minta."

Berjalannya peran ekonomi pada masjid zaman sekarang tidak sepenuhnya dapat membantu masyarakat sekitar, ini berarti peran ekonomi yang dilakukan belum maksimal. Hal ini tidak sejalan dengan peran masjid di zaman Rasulullah, yang mana beliau membangun baitul maal bertujuan untuk mendistribusikan harta kepada yang membutuhkan, sehingga masyarakat sangat terbantu dengan adanya baitul maal tersebut. hal tersebut dibuktikan dengan riwayat-riwayat yang menyebutkan pendelegasian tugas Baitul Maal oleh Rasulullah Shalallahu alaihi wa salam kepada beberapa orang sahabat tertentu, seperti tugas pencatatan, tugas penghimpunan zakat hasil pertanian, tugas pemeliharaan zakat hasil ternak dan juga pendistribusian. Selanjutnya dimasa kekhalifahan Abu Bakar tidak terlalu ada perubahan yang besar berkaitan dengan Baitul Maal. Perubahan yang besar terjadi pada masa kekhalifahan Umar bin Khattab dengan dioperasikannya system administrasi pencatatan dengan system Ad Diwan. Secara tidak langsung, baitul 
maal berfungsi sebagai pelaksana kebijakan fiskal dan khalifah menjadi pihak yang berkuasa penuh terhadap harta baitul maal. ${ }^{23}$

Selanjutnya Baitul Maal semakin berkembang dimasa-masa selanjutnya (dinasti Abasiyah dan Umayah) Baitul Maal telah menjadi lembaga penting bagi Negara (mulai dari penarikan zakat (juga pajak), ghonimah, kharaj, sampai membangun jalan, menggaji tentara dan juga pejabat Negara serta membangun sarana sosial). ${ }^{24}$

\section{Sosial}

Masjid merupakan tempat silaturahmi jama'ah. Dengan berkumpulnya jama'ah setiap hari akan menumbuhkan ikatan persaudaraan yang kuat. Sehingga umat Islam tidak mudah digoyahkan oleh permasalahan-permasalahan lain. Masjid Haji Maraset menjadikan masjid sebagai tempat silaturahmi. Dalam hal ini Muhammad Yudi ${ }^{25}$ menuturkan bahwa:

"Masjid adalah tempatnya kami berkumpul dengan tetangga. Selain di masjid, kami akan sangat jarang bertemu dengan tetangga dikarenakan aktifitas kami masing-masing. Hanya diwaktu singkat ini saja kami dapat bertegur sapa dengan tetangga."

Mereka sering berkumpul di masjid sewaktu shalat fardhu tiba. Tetapi, berkumpulnya jama'ah di masjid tidak digunakan untuk mengenal satu sama lain, tidak digunakan untuk memahami keadaan sesama jama'ah, banyak dari mereka yang acuh tak acuh dengan sesamanya, tidak berusaha untuk menyelesaikan masalah saudara seimannya. Hakikat output dari peran sosial harusnya menumbuhkan rasa persaudaraan yang kuat dan teguh. Namun, di zaman sekarang, peran sosial tidak berjalan secara maksimal sehingga output yang di harapkan tidak di dapat. Hal ini dibuktikan dengan masih adanya ketidakpedulian antar tetangga.

Seharusnya, jika dilihat sejarah pembangunan masjid pertama sekali oleh Nabi Muhammad SAW, salah satu peranannya adalah untuk kepentingan sosial, yaitu untuk mempersatukan kaum Muhajirin dan Anshar serta meningkatkan Ukhuwah antar umat beragama di kota Yastrib. Bahkan di masjid dibuat sebuah tenda tempat memberi santunan uang dan makanan kepada fakir miskin. Masalah pernikahan, perceraian, perdamaian dan penyelesaian sengketa masyarakat juga diselesaikan di masjid. ${ }^{26}$ 


\section{Analisis Model Pemberdayaan Ekonomi terhadap Kemandirian Masjid Haji Maraset}

Era globalisasi ini ditandai, diantaranya dengan adanya fenomena penting dalam bidang ekonomi. Kegiatan ekonomi dunia tidak hanya dibatasi oleh faktor geografi, bahasa, budaya dan ideologi, akan tetapi lebih karena faktor saling membutuhkan dan saling bergantung satu sama lain. Dunia menjadi seakan-akan tidak ada batas, terutama karena perkembangan teknologi informasi yang begitu pesat. Keadaan yang demikian melahirkan banyak peluang sekaligus tantangan, terutamanya dalam upaya pengembangan ekonomi Islam.

Hal ini juga akan berdampak kepada eksistensi masjid dalam perkembangan ekonomi di era globalisasi ini. Pengurus Masjid Haji Maraset senantiasa melakukan perbaikan-perbaikan dalam sistem manajemen dan administrasinya. Mereka dituntut bekerja ekstra untuk bisa mempertahankan dan mengembangkan usaha dengan memanfaatkan potensi yang tersedia.

Pengurus Masjid Haji Maraset diharapkan kedepan menjadi pengurus yang dinamis artinya mereka selalu memantau perkembangan-perkembangan terbaru yang berkaitan dengan upaya pengembangan ekonomi masjid melalui pemanfaatan teknologi informasi. Dengan begitu Masjid Haji Maraset akan memiliki pola managemen pengelolaan bisnis yang baik, yang selalu mengikuti tuntunan dan kebutuhan masyarakat sekitar masjid.

Kini yang menjadi fokus pengurus masjid Haji Maraset adalah bagaimana memaksimalkan bidang usaha yang memanfaatkan segala potensi yang dimiliki oleh masjid, baik itu potensi jama'ah, potensi lokasi masjid, potensi ekonomi masyarakat sekitar masjid, dan potensi-potensi lainnya. Bila kesemua potensi tersebut dapat dikelola dengan baik, maka pengurus berkeyakinan bahwa tidak hanya masjid saja yang mandiri akan tetapi masjid pun juga mampu membantu problematika pengangguran dan kemiskinan, yang menjadi musuh utama umat Islam dewasa ini, akan dapat diminimalisasi.

Kemampuan Masjid Haji Maraset dalam melaksanakan kegiatankegiatannya tidak bisa dilepaskan dari peranan kegiatan usaha yang ada. Kontribusi yang diberikan memang belum bisa menutupi kebutuhan masjid secara keseluruhan. Namun rasa optimisme terhadap kegiatan usaha ini terus didengungdengungkan agar setiap pengurusnya memiliki semangat untuk bisa mengembangkan kegiatan usaha masjid ini dengan lebih baik kedepannya. 
Berikut ini analisa agenda kegiatan pemakmuran Masjid Haji Maraset dikaitkan dengan kemampuan masjid bersifat mandiri.

Tabel 3 Agenda Kegiatan Pemakmuran Masjid Haji Maraset

\begin{tabular}{|c|c|c|c|c|}
\hline No & Keterangan & Intensitas & $\begin{array}{l}\text { Total } 1 \\
\text { tahun }\end{array}$ & $\begin{array}{l}\text { Presentase } \\
\text { Penggunaan } \\
\text { dana }\end{array}$ \\
\hline 1 & Pengajian minggu & $1 \mathrm{x} 1$ minggu & $4 \times 12=48$ & \multirow{6}{*}{$26.74 \%$} \\
\hline 2 & Pengajian tafsir dan fiqh & $1 \times 1$ minggu & $4 \times 12=48$ & \\
\hline 3 & Zikir akbar & $1 \times 1$ tahun & 1 & \\
\hline 4 & Tablig akbar & $1 \times 1$ tahun & 1 & \\
\hline 5 & Tafakur akhir tahun & $1 \times 1$ tahun & 1 & \\
\hline 6 & Tahun baru hijriyah & $1 x 1$ tahun & 1 & \\
\hline 7 & Tarawih & $1 \times 30$ hari & 30 & \multirow{2}{*}{$11.23 \%$} \\
\hline 8 & Kegiatan ramadhan & $1 \times 1$ tahun & 1 & \\
\hline 9 & Idul fitri & $1 \times 1$ tahun & 1 & \multirow{4}{*}{$10.70 \%$} \\
\hline 10 & Idul adha & $1 \times 1$ tahun & 1 & \\
\hline 11 & Qurban & $1 \times 1$ tahun & 1 & \\
\hline 12 & Haji dan umrah & $1 \times 1$ tahun & 1 & \\
\hline \multicolumn{4}{|c|}{ Total pemakaian dana pemakmuran masjid } & $48.67 \%$ \\
\hline
\end{tabular}

Dari analisis yang sudah di uraikan diatas ada tiga alasan Masjid Haji Maraset diketegorikan masjid yang Mandiri:

a) Dapat mendanai kegiatan-kegiatan yang telah direncanakan masjid dengan optimalisasi potensi sumber dana yang dimiliki oleh masjid.

b) Memiliki kemampuan untuk menghasilkan income secara profesional melalui optimalisasi pemberdayaan asset masjid.

c) Profesionalisme manajemen dalam seluruh kegiatan dan pemakmuran masjid.

\section{Kesimpulan}

Berdasarkan hasil penelitian di lapangan yang diperoleh dari observasi, wawancara dan dokumentasi, maka dapat disimpulkan beberapa hal sebagai berikut:

1. Di dalam kepengurusan Masjid Haji Maraset, bidang usaha memiliki peranan yang sangat penting dalam upaya menciptakan masjid yang mandiri, dengan menghadirkan berbagai kegiatan-kegiatan usaha yang 
mampu memberikan kontribusi kepada berbagai kegiatan masjid baik itu syiar maupun kegiatan operasional masjid, sehingga masjid tidak lagi hanya bergantung kepada donatur dalam melaksanakan kegiatan memakmurkan masjid.

2. Faktor keberhasilan pengelola Masjid Haji Maraset dalam memberdayakan potensi masjid ditunjang dari berbagai aspek, meliputi:

a) Faktor strategis posisi masjid yang berada di tengah pemukiman yang ramai dengan masyarakat lapis menengah dan terpelajar.

b) Faktor manajemen yang dikelola dengan baik oleh pengelola dengan latar belakang pengalaman serta pendidikan yang mendukung.

3. Kekurangan sumber daya manusia dalam pelaksanaan kegiatan usaha tersebut. Karena selama ini pengurus masjid Haji Maraset merupakan orang-orang pekerja yang kesehariannya sibuk dengan rutinitas mereka masing-masing dan hanya bisa fokus dalam kegiatan masjid pada saat libur kerja atau libur-libur nasional. Sedangkan yang selalu ada di masjid hanya beberapa orang saja. Sehingga ada beberapa program kerja yang sudah dirancang tidak dapat berjalan dengan baik. 1971), h. 27.

\section{Catatan}

${ }^{1}$ Q.S. al-Jinn (72): 18.

${ }^{2}$ Sidi, Gazalba, Masjid Pusat Ibadat dan Kebudayaan Islam (Jakarta: Pustaka Antara,

${ }^{3}$ Ahmad Yani, Panduan Memakmurkan Masjid (Jakarta: Dea Perss, 2000), hal. 11. 2004), h. 5 .

${ }^{4}$ H. Noer Chaniago, Tingkatkan Peran Ubudiyah Masjid (Jakarta: Republika, 4 Maret

${ }^{5}$ H. Juned Nasution, Badan Kenaziran Masjid H. Maraset, wawancara di Medan Barat, tanggal 24 Maret 2018.

${ }^{6}$ Supardi \& Teuku Amiruddin, Konsep Manajemen Masjid: optimalisasi peran masjid (Yogyakarta: UII Press, 2001), h. 3.

${ }^{7}$ Moh. E. Ayub, dkk. Manajemen Masjid (Jakarta : Gema Insani Press, 1996), h. 17.

8 Agustianto, Peran Masjid dalam Edukasi Syariah, http://www.pesantrenvirtual.com. Diakses pada tanggal 20 Maret 2018

${ }^{9}$ H. Juned Nasution, Badan Kenaziran Masjid H. Maraset, wawancara di Medan Barat, tanggal 24 Maret 2018.

10 A. Muri Yusuf, Metode Penelitian Kuantitatif, Kualitatif, dan Penelitian Gabungan (Jakarta: Prenadamedia Group, 2014), h. 329.

${ }^{11}$ Rulam Ahmadi, Metode Penelitian Kualitatif (Yogyakarta: Ar-Ruzz Media, 2016), h. 15. 
${ }^{12}$ Ahmad Wahyu, Pengertian, tujuan pendidikan disekolah dasar, http://blogwahyu.com. /2013/11/pusat-pendidikan-anak.html. diakses pada 10 September 2018

${ }^{13}$ Laporan keuangan sekolah Arsyadiyah tahun 2017.

${ }^{14}$ Laporan keuangan sekolah Arsyadiyah per Januari-September 2018.

${ }^{15}$ Laporan keuangan Masjid Haji Maraset per Januari-September 2018.

${ }^{16}$ Syarifuddin Lubis, Badan Kenaziran Masjid H. Maraset, wawancara di Medan Barat, tanggal 05 September 2018.

${ }^{17}$ Anwar Effendi Nasution, berperan sebagai sekretariat Masjid Haji Maraset, dialah yang memiliki tanggung jawab untuk mengurusi pelaksanaan shalat.

${ }^{18}$ Ahmad Hasan salah satu jama'ah tetap Masjid Haji Maraset.

${ }^{19}$ Q.S. al-Ankabut (29): 45.

${ }^{20}$ Liputan 6, pelecehan seksual, http://www.liputan6.com/tag/pelecehan-seksual. Diaskses pada tanggal 10 September 2018

${ }^{21}$ Pardamean Lubis merupakan koordinator seksi Dakwah Masjid Haji Maraset.

${ }^{22}$ Muhammad Husein Haikal, Sejarah Hidup Muhammad (Jakarta: PT. Mitra Kerjaya Indonesia, 2001), h. 546.

${ }^{23}$ Yogio Respati, Baitul Maal di Masa Umar bin Khattab, http://mysharing.com/baitulmal-di-masa-umar-bin-khattab/. Diakses pada tanggal 8 September 2018

24 Rumah Dhuafa Indonesia, Sejarah Baitul Maal dari Masa ke Masa, http://rumahdhuafa.com/sejarah-baitul-maal-dari-masa-ke-masa/. Diakses pada tanggal 8 September 2018

${ }^{25}$ Muhammad Yudi, merupakan salah satu pengurus di Masjid Haji Maraset, yaitu sebagai wakil ketua BKM.

${ }^{26}$ Pondok pesantren Daaruttauhid, Mengenang Fungsi Masjid di Zaman Rasulullah, http://www.daaruttauhid.org/artikel-islami/265/mengenang-fungsi-masjid-di-zaman-rasulullah html. diakses 09 September 2018

\section{Daftar Pustaka}

Al Quran Dan Terjemahnya, Jakarta: Departemen Agama RI, 1987.

Afrizal. Metode Penelitian Kualitatif, Jakarta: Rajawali Pers, 2014.

Agustianto, Peran Masjid dalam Edukasi Syariah, http://www.pesantrenvirtual.com. Diakses pada tanggal 20 Maret 2018.

Ahmadi, Rulam. Metode Penelitian Kualitatif, Yogyakarta: Ar-Ruzz Media, 2016.

Antonio, Muhammad Syafi'i. bank syariah dari teori ke praktek, Jakarta: Gema Insani, 2001.

Asrori, Mohammad. Psikologi Pembelajaran, Bandung: CV Wacana Prima, 2009.

Ayub, Moh. E, dkk. Manajemen Masjid, Jakarta: Gema Insani Press, 1996.

Aziz, Abdul dan Mariyah Ulfah. Kapita Selekta Ekonomi Islam Kontemporer, Bandung: Alfabeta CV, 2010.

Buchari, Alma, dkk. Manajemen Bisnis syariah, Bandung: Alfabeta, 2009. 
Cayaray, Sartiaji. model layanan perpustakaan sekolah luar biasa Universitas Pendidkian Indonesia. perpustakaan.upi.edu. 2014.

Chaniago, H Noer. Tingkatkan Peran Ubudiyah Masjid, Jakarta: Republika, 2004.

Ekonisia, Sutrisno. Manajemen Keuangan, Teory, konsep dan Aplikasi, Yogyakarta: Mulya Pustaka, 2000.

Gazalba, Sidi. Masjid Pusat Ibadat dan Kebudayaan Islam, Jakarta: Pustaka Antara, 1971.

Haikal, Muhammad Husein. Sejarah Hidup Muhammad, Jakarta: PT. Mitra Kerjaya Indonesia, 2001.

Handoko, T. Hani. Manajemen Personalia dan Sumber Daya Manusia, Yogyakarta: PT. Liberty, 1985.

Harahap, Sofyan Syafri. Manajemen Masjid, Yogyakarta: Bhakti Prima Rasa, 1996.

Pedoman Manajemen Masjid, Jakarta: Pustaka Quantum, 2004.

Hasan, Ahmad. Salah satu jama'ah tetap Masjid Haji Maraset.

Hendi, Suhendi. Fiqh Muamalah, Bandung: PT Raja Grafindo Persada, 2010.

Ibnu, Banyu Ardi. Peranan Bidang Usaha Dalam Kemandirian Masjid Ittihadul Muhajirin Pamulang, Skripsi, UIN Syarif Hidayatullah Jakarta, 2013.

Idrus, Muhammad. Metode Penelitian Ilmu Sosial, Yogyakarta: Erlangga, 2009.

Laporan keuangan Masjid Haji Maraset. , Sekolah Arsyadiyah Masjid Haji Maraset.

Liputan 6. Pelecehan seksual, http://www.liputan6.com/tag/pelecehan-seksual. Diaskses pada tanggal 10 September 2018.

Lubis, Pardamean. Merupakan koordinator seksi Dakwah Masjid Haji Maraset.

Lubis, Syarifuddin. Badan Kenaziran Masjid H. Maraset, wawancara di Medan Barat, tanggal 05 September 2018.

Mardani. FIQH Ekonomi Syariah: Fiqh Muamalah, Jakarta: Prenadamedia, 2012.

Nasution, Anwar Effendi. Berperan sebagai sekretariat Masjid Haji Maraset.

Nasution, H. Juned. Badan Kenaziran Masjid H. Maraset, wawancara di Medan Barat, tanggal 24 Maret 2018.

Pasaribu, Chairuman dan k. Lubis. Hukum perjanjian dalam islam, Jakarta: sinar Grafika, 1996. 
Pondok pesantren Daaruttauhid. Mengenang Fungsi Masjid di Zaman Rasulullah, http://www.daaruttauhid.org/artikel-islami/265/mengenang-fungsimasjid-di-zaman-rasulullah html. diakses 09 September 2018.

Respati, Yogio. Baitul Maal di Masa Umar bin Khattab, http://mysharing.com/baitul-mal-di-masa-umar-bin-khattab/. Diakses pada tanggal 8 September 2018.

Rumah Dhuafa Indonesia. Sejarah Baitul Maal dari Masa ke Masa, http://rumahdhuafa.com/sejarah-baitul-maal-dari-masa-ke-masa/.

Diakses pada tanggal 8 September 2018.

Sarwono, Jonathan. Metode Penelitian Kuantitatif dan Kualitatif, Yogyakarta: Graha Ilmu, 2006.

Satria, Ase. Pengertian model menurut para ahli, http://www. materibelajar.id. Diakses pada tanggal 15 Maret 2018.

Sugioyono. Metode Penelitian Bisnis, Bandung: Alfabeta CV, 2008.

Suhrawadi, Lubis, dkk. Hukum Ekonomi Islam, Jakarta: Kencana, 2006.

Supardi dan Teuku Amiruddin. Konsep Manajemen Masjid: optimalisasi peran masjid, Yogyakarta: UII Press, 2001.

Sutarmadi, Ahmad. Visi, Misi, dan Langkah strategis PDMI dan pengelola Masjid, Jakarta: Logos Wacana Ilmu, 2002.

Sutarmadji, A dan Al Tirmidzi. Model dan Pengembangan Hadist dan Fiqih, Ciputat: Logo Wacana Ilmu, 1998.

Syawaluddin. Badan Kenaziran Masjid H. Maraset, wawancara di Medan Barat, tanggal 03 September 2018.

Tarigan, Azhari Akmal. Dari Etika Ke Spritualitas Bisnis, Medan: Iain Press, 2014).

Tasmara, Toto. Etos Kerja Pribadi Muslim, Yogyakarta: Dana Bakti Wakaf, 1995.

Tim Penyusun Kamus Pusat Pembinaan dan Pengembangan Bahasa. kamus Besar Bahasa Indonesia, Jakarta: Balai Pustaka, 1988.

Tina, Afriani. Manajemen Pemberdayaan Ekonomi pada Masjid Sunda Kelapa, Skripsi, UIN Syarif Hidayatullah Jakarta, 2005.

Wahyu, Ahmad. Pengertian, tujuan pendidikan disekolah dasar, http://blogwahyu.com./2013/11/pusat-pendidikan-anak.html. diakses pada 10 September 2018.

Yani, Ahmad dan Achmad Satori Ismail. Menuju Masjid Ideal, Jakarta: LP2SI Al Haramain, 2001.

Yani, Ahmad, dkk. Panduan Mengelola Masjid, Jakarta: Pustaka Intermasa, 2007. 
443 | At-Tawassuth, Vol. III, No. 2, 2018: 423 - 443

Yani, Ahmad. Panduan Memakmurkan Masjid, Jakarta: Dea Perss, 2000.

Yudi, Muhammad. Merupakan salah satu pengurus di Masjid Haji Maraset.

Yusuf, A. Muri. Metode Penelitian Kuantitatif, Kualitatif, dan Penelitian

Gabungan, Jakarta: Prenadamedia Group, 2014. 